\title{
Z PROBLEMATYKI RETRYBUTYWNEJ ORAZ UTYLITARNEJ SPRAWIEDLIWOŚCI KARANIA
}

\section{WPROWADZENIE}

Rozpoznanie istoty sprawiedliwości wzbudza liczne kontrowersje interpretacyjne ${ }^{1}$. Nie bez racji podkreśla się więc w piśmiennictwie, że trudno byłoby $\mathrm{w}$ istocie wypracować jednoznaczne oraz uniwersalne wyjaśnienie, czym de facto jest sprawiedliwość i na czym polega stosowanie się do jej wymagań2. Z doktrynalnych rozważań wynika bowiem, że analizowana sprawiedliwość uzyskuje nierzadko status symbolu, „poręczającego za dobre zamiary lub wyrażającego zakładany konsens"3. Ponadto zakresowa nieostrość objaśnianej sprawiedliwości przesądza również o tym, że jej analiza pozostaje każdorazowo narażona na szczególne, „semantyczne nadużycia”4

Pomimo zasygnalizowanych trudności interpretacyjnych, należy jednak w tym miejscu stwierdzić, że w ramach filozoficznoprawnej refleksji nad problematyką sprawiedliwości nie zabrakło również konkretnych oraz zwięzłych ujęć tego pojęcia. Już bowiem w starożytnej myśli Platońskiej można odnaleźć stwierdzenie, że sens wspomnianej wartości - pojmowanej jako cnota i mą-

${ }^{1}$ O pojęciu, jak również sposobach pojmowania sprawiedliwości zob. m.in. Arystoteles, Etyka nikomachejska, Warszawa 2011, s. 79; Z. Ziembiński, O pojmowaniu sprawiedliwości, Lublin 1992, s. 18; K. Ajdukiewicz, Język i poznanie, t. 1, Warszawa 1960, s. 365; J. Karp, Sprawiedliwość społeczna. Szkice ze wspótczesnej teorii konstytucjonalizmu i praktyki polskiego prawa ustrojowego, Kraków 2004, s. 69; M. Zalewska, Racjonalne koncepcje sprawiedliwości $w$ ocenie Hansa Kelsena, w: B. Wojciechowski, M.J. Golecki (red.), Rozdroża sprawiedliwości we wspótczesnej myśli filozoficznoprawnej, Toruń 2008, s. 53 i n.; T. Orczykowski, Szkoła psychologiczna w prawie, Toruń 2007, s. 56-57; S.J. Karolak, Sprawiedliwość. Sens prawa. Eseje, Kraków 2005, s. 9.

${ }^{2}$ M. Łoś-Bobińska, Zasady wymiaru sprawiedliwości w świetle badań ankietowych, „Etyka” 1968, nr 3, s. 162; por także T. Kaczmarek, Sędziowski wymiar kary w Polskiej Rzeczpospolitej Ludowej $w$ świetle badań ankietowych, Wrocław-Warszawa-Kraków-Gdańsk 1972, s. 70-71; A. Perelman, O sprawiedliwości, tłum. W. Bieńkowska, Warszawa 1959, s. 22; M. Szerer, Problematyka społecznego oddziaływania kary, „Państwo i Prawo” 1974, z. 5, s. 19. W prezentowanej wypowiedzi autor jednocześnie zaznaczył, że: „[...] słynne cyceronowe sformułowanie, że iustitia suum cuique distribuit, okazuje się zwodnicze, bo jak przydzielać każdemu, co mu się należy, skoro nie wiadomo właśnie, co się komu należy".

${ }^{3}$ B. Janiszewski, „Sprawiedliwość” kary. Rozważania w świetle prawnych podstaw jej wymiaru, w: A.J. Szwarc (red.), Rozważania o prawie karnym. Księga pamiatkowa z okazji siedemdziesięciolecia urodzin Profesora Aleksandra Ratajczaka, Poznań 1999, s. 169.

${ }^{4}$ J. Winczorek, Sprawiedliwość jako przedmiot badań i jako problem w socjologii prawa, w: B. Wojciechowski, M.J. Golecki (red.), op. cit., s. 36. 
drość - sprowadza się w istocie do tego, aby: „[...] każdy miał to, co jest jego

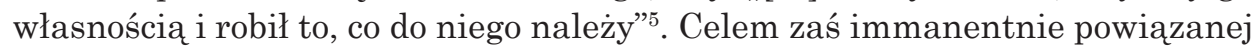
ze sprawiedliwością - sprawiedliwej kary - było, jak przekonywał antyczny filozof: „[...] uczynienie lepszym tego, kto ją znosi, a zatem przyniesienie mu korzyści, albo stanie się przestroga dla innych, by ci widząc takie cierpienia z obawy stawali się lepsi”". Do przedstawionej powyżej sui generis definicji nawiązywała również formuła sprawiedliwości, którą zaproponował Ulpian, kwalifikując tę ostatnią jako stałą oraz niezmienną wolę przyznawania każdemu należnego mu prawa ${ }^{7}$. Z kolei dla Cycerona iustitia uosabiała najwyższa cnotę, wyróżnioną obok roztropności, męstwa i powściąliwości, której wyekstrahowanie wynikało z powszechnej użyteczności i zapewnienia każdemu poczucia jego osobistej wartości ${ }^{8}$. Podobna - równie doniosłą wartość - przypisał sprawiedliwości Arystoteles, który utożsamił ją nie tylko z „największą cnotą”, lecz także z „doskonałością etyczną”, traktując tym samym wszelkie przejawy niesprawiedliwości w kategoriach „wad etycznych”.

Podejmowanie dalszych starań przybliżajacych sens analizowanego pojęcia dostrzega się również $\mathrm{w}$ pracach myślicieli późniejszych epok ${ }^{10}$. Spośród najbardziej interesujących ujęć warto odwołać się m.in. do słów twórcy koncepcji trójpodziału władzy - Monteskiusza, dla którego sprawiedliwość stanowiła: „[...] wykładnik realnego stosunku między dwiema rzeczami”"11. Z kolei w poglądach Kanta, sens sprawiedliwości sprowadzał się do imperatywu kategorycznego, głoszącego: „[...] postępuj zawsze tak, jak byś chciał, żeby postępowali twoi bliźni, według takiej maksymy, dzięki której chcesz, aby stała się powszechnym prawem"12. W jeszcze zaś innym ujęciu przekonywano, że sprawiedliwość należy utożsamić z bezstronnościa, której deontologiczne założenia miały stanowić przeciwwagę dla teorii utylitarnej, eksponującej zasadę

${ }^{5}$ S. Zabłocki, Pojęcie sprawiedliwości w myśli etycznej i penologicznej Bronisława Wróblewskiego, w: A. Dębiński, A. Grześkowiak, K. Wiak (red.), Ius et lex. Księga jubileuszowa ku czci Profesora Adama Strzembosza, Lublin 2002, s. 90.

${ }_{6}$ J. Warylewski, Kara. Podstawy filozoficzne i historyczne, Gdańsk 2007, s. 35; J. Makarewicz, Prawo karne ogólne, Kraków 1914, s. 36.

7 A. Plisecka, Definicja sprawiedliwości $w$ filozofii Cycerona $i$ w prawie rzymskim, „Studia Iuridica" 40, 2002, s. 131.

8 Cyceron twierdził, że: „Albowiem bez sprawiedliwości świat straciłby zupełnie swą wartość i nie byłoby miejsca dla pozostałych cnót, tak iż działyby się jeno same morderstwa, podpalenia, zdrady, krzywdy i inne nieszczęścia znacznie gorsze niż te, które dotykają nas dzisiaj; a przez nie świat nieuniknienie musiałby zginąć”; cyt. za: ibidem, s. 132.

${ }^{9}$ M. Augustyniak, Sprawiedliwość w myśli Arystotelesa, w: B. Kruszewska, P. Polaczuk, L. Świto (red.), Sprawiedliwość. Wybrane koncepcje, Olsztyn 2010, s. 5; J. Warylewski, op. cit., s. 36.

10 Antyczni Grecy oddawali cześć „Sprawiedliwości” pod dwiema postaciami. Uosabiały ją Temida, symbolizująca czystość oraz stanowiąca: „[...] wskazówkę, że nigdy nie ustapiła przed złoczyńcami, nigdy nie ugięła się przed zgrabną mowa, modlitwa, błaganiem, zawodzeniem ani niczym w tym rodzaju”, oraz Astrea, która, zgodnie z dawnymi wierzeniami, opuściła ziemski padół i udała się do niebios, jaśniejąc obecnie jako konstelacja Panny. Natomiast starożytni Rzymianie czcili „Sprawiedliwość” w dwóch bóstwach, nazywanych Iustitia oraz Aequitas. M. Jońca, Jak powinna wygladać Sprawiedliwość?, „Edukacja Prawnicza” 2009, nr 11, s. 33-34.

11 S. Zabłocki, op. cit., s. 90.

12 Ibidem, s. 90-91. 
maksymalizacji dóbr ${ }^{13}$. W ostatnim z zaprezentowanych stanowisk podkreślano jednocześnie ponadczasowy charakter analizowanego pojęcia, napominając w konsekwencji, że tak: „Jak prawda w systemach wiedzy, tak sprawiedliwość jest pierwszą cnotą społecznych instytucji”"14.

Ponadto dla definicyjnych rozważań poświęconych objaśnieniu „sprawiedliwości” znamienne okazało się również filozoficzne przeświadczenie Gustava Radbrucha, argumentującego, że ideą prawa nie powinno pozostawać nic innego, niż sprawiedliwośćc ${ }^{15}$. Zasygnalizowana $\mathrm{w}$ ten sposób ścisła relacja akcentująca powiązania, zachodzące pomiędzy prawem a sprawiedliwością ${ }^{16}$ - nakazywałaby zatem przyjać, że rozwiązania normatywne powinny stanowić odzwierciedlenie sformalizowanej oraz zinstytucjonalizowanej sprawiedliwości ${ }^{17}$. W istotę zaprezentowanego stanowiska wpisywały się zatem słowa, że: „[...] prawo bez sprawiedliwości byłoby martwym wrakiem. Owszem, można sobie wyobrazić takie prawo: Byłby to zespół reguł technicznych obliczonych na zdyscyplinowanie społeczeństwa jako swoista tresura"18. W świetle powyższego ujęcia sprawiedliwość uzyskała więc przymiot „naczelnej wartości prawa"19, nawiązując w konsekwencji do samej etymologii wspomnianych pojęć. Łacińskie słowo ius, oznaczające prawo, pozostaje bowiem w bliskim pokrewieństwie z określeniem iustitia, tłumaczonym jako „sprawiedliwość”. Jurydyczne tło sprawiedliwości sugerowałoby tym samym, że sprawiedliwość należy łączyć czy wręcz utożsamić z prawem - z nadaną mu treścia, jak również z kwestiąjego przestrzegania bądź nierespektowania ${ }^{20}$. Eksponując wspomnianą zależność językowa, w doktrynie przedmiotu zaproponowano wyróżnienie jeszcze innych powiązań (funkcjonalno-ideologicznych), zachodzących

${ }^{13}$ Warto w tym miejscu podkreślić, że główne założenia „sprawiedliwości” J. Rawls prezentował na płaszczyźnie umowy społecznej, którą określał mianem sytuacji hipotetycznej, pierwotnej, oddającej sens stanu natury. Z kolei do elementów konstruujących sytuację pierwotną autor ten zaliczył: zasłonę niewiedzy (partnerzy umowy społecznej nie wiedzieli bowiem o swoim miejscu w społeczeństwie, pozycji ani statusie), osoby hipotetyczne (które znamionowało posiadanie ogólnej wiedzy, racjonalność, plany życiowe, wolność) oraz otoczenie sprawiedliwości (warunki życiowe, z których wynika, że współpraca międzyludzka jest możliwa i konieczna); krytycznie o założeniach wymienionej teorii - O. Höffe; S. Lis, Otfrieda Höffego teoria sprawiedliwości, Tarnobrzeg 2008, s. 55 i n.

14 S. Zabłocki, op. cit., s. 91.

15 G. Radbruch, Zarys filozofii prawa, Warszawa-Kraków 1938, s. 41. Nie bez znaczenia pozostaje również przekonanie Stagiryty, który stwierdził, że o sprawiedliwości „można mówić tam, gdzie wzajemne stosunki między ludźmi unormowane są przez jakieś prawo, prawo zaś istnieje wśród ludzi, wśród których możliwa jest niesprawiedliwość; bo wyrok sądu jest rozstrzygnięciem, co jest sprawiedliwe, a co niesprawiedliwe”. Cyt za: J.M. Kelly, Historia zachodniej teorii prawa, tłum. Ł. Słoniowski, Kraków 2006, s. 47.

${ }_{16} \mathrm{~W}$ ocenie H. Rota problematyka relacji zachodzących między pojęciem sprawiedliwości a pojęciem prawa jest w istocie tak „stara jak świat, zawsze pasjonująca i wciąż ważka społecznie", idem, Elementy teorii prawa, Wrocław 1992, s. 159.

17 F. Ciepły, Sprawiedliwość karania a prawo łaski - uwagi krytyczne, „Przegląd Prawno-Ekonomiczny" 2008, nr 3, s. 34.

18 M. Cieślak, Polskie prawo karne. Zarys systemowego ujęcia, Warszawa 1994, s. 127.

19 R.A. Tokarczyk, Sprawiedliwość jako naczelna wartość prawa, „Państwo i Prawo” 1997, z. 6, s. 3-4.

20 S.J. Karolak, op. cit., s. 10. 
pomiędzy wymienionymi pojęciami (prawo-sprawiedliwość), które jeszcze bardziej sugestywnie przekonywały o bliskiej relacji czy wręcz o ich wzajemnym sprzężeniu ${ }^{21}$. Z drugiej jednak strony - o czym warto również wspomnieć - w piśmiennictwie starano się zwrócić uwagę na pewne niebezpieczeństwo wiążące się z bezrefleksyjnym utożsamianiem prawa ze sprawiedliwością. Nie zaprzeczając doniosłości wysuwanej w literaturze tezie, akcentującej związek prawa ze sprawiedliwościa, trzeba bowiem stwierdzić, że nie każde prawo jest zdolne do realizacji sprawiedliwości. Podnosząc wskazany problem, stwierdzono, że zdolne do tego okazywało się jedynie prawo korelujące z aprobowanymi wartościami o charakterze aksjologicznym (moralnym) ${ }^{22}$. Z perspektywy historycznej przytoczona wypowiedź znajduje zaś niewątpliwie wymowne odzwierciedlenie w „zachwianym” zaufaniu do prawa stanowionego, m.in. w okresie totalitaryzmu oraz komunizmu ${ }^{23}$.

Zaprezentowane poglądy utwierdzają niewątpliwie w przekonaniu, że próba zdefiniowania sprawiedliwości stanowi jedno z najbardziej intrygujących wyzwań współczesności. Dostrzegając relewantność tego zadania nie sposób byłoby jednak rozproszyć podejrzeń, iż próba konstruowania ścisłych, podręcznikowych definicji sprawiedliwości jest nie tylko skazana na niepowodzenie, lecz także raziłaby swoją arbitralnością̨ ${ }^{24}$.

\section{RETRYBUTYWNE ORAZ UTYLITARNE UJĘCIE SPRAWIEDLIWOŚCI KARANIA}

Rozważając ideę sprawiedliwości na tle retrybutywnej oraz utylitarnej teorii kary, należałoby w pierwszej kolejności przypomnieć słowa Edmunda Krzymuskiego, który - podkreślając szczególne znaczenie zasady sprawiedliwości na

${ }^{21}$ R.A. Tokarczyk, Sprawiedliwość..., s. 3-4. Autor wskazał zatem nie tylko na powiązania treściowe pomiędzy cytowanymi terminami, ale również zwrócił uwagę na powiązania o charakterze funkcjonalnym, dostrzegając realizację sprawiedliwości przez prawo; idem, Filozofia prawa, Lublin 2001, s. 211.

22 Ibidem.

23 Słusznie zauważył zatem J. Laskowski, że utożsamienie sprawiedliwości z prawem okazać się może błędne oraz niebezpieczne. Autor ten stwierdził bowiem, że: „Wiadomo, że można tworzyć prawa zarówno sprawiedliwe, jak i niesprawiedliwe. Kiedy mamy do czynienia z prawem niesprawiedliwym, wtedy przestrzeganie zasad prawa będzie niesprawiedliwością. Zob. idem, Sprawiedliwość a prawo, w: B. Czech (red.), Filozofia prawa a tworzenie $i$ stosowanie prawa. Materiały Ogólnopolskiej Konferencji Naukowej zorganizowanej w dniach 11 i 12 czerwca 1991 roku w Katowicach, Katowice 1992, s. 134; J. Zajadło, Gustaw Radbruch i antynomie współczesnej filozofii prawa, „Colloquia Communia” 1988-1989, nr 6, s. 63-75. Zob. także A. Grabowski, Prawnicze pojęcie obowiazywania prawa stanowionego. Krytyka niepozytywistycznej koncepcji prawa, Kraków 2009, s. 13-15; J. Zajadło, Formuła Radbrucha. Filozofia prawa na granicy pozytywizmu prawniczego i prawa natury, Gdańsk 2001, s. 105 i n.; idem, Dziedzictwo przeszłości. Gustaw Radbruch: portret filozofa, prawnika, polityka i humanisty, Gdańsk 2007, s. 206 i n.; idem, Formuła Radbrucha a paradygmat niepozytywistycznej teorii prawa, „Gdańskie Studia Prawnicze” 2000, s. 687 i n.; R. Alexy, Mauerschützen. Zum Verhältnis von Recht, Moral und Strafbarkeit, Hamburg-Göttingen 1993, s. 4.

${ }^{24}$ M. Łoś-Bobińska, op. cit., s. 177. 
płaszczyźnie prawnokarnej - nie bez racji napominał, iż naród, który raz od niej odstapi, nie będzie przestrzegał tej najważniejszej reguły sądzenia także w przyszłości ${ }^{25}$. Pogłębiając karnistyczną refleksję nad tytułową problematyka, należałoby przede wszystkim odwołać się do dwóch wielkich tradycji sprawiedliwościowych: 1) teorii nawiązujących do założeń prawa naturalnego oraz 2) teorii utylitarnych, utożsamiajacych istotę sprawiedliwości z dążeniem do zapewnienia szczęśliwego bytowania całemu społeczeństwu ${ }^{26}$. Zasadnicza różnica między wspomnianymi teoriami sprowadzała się zaś do tego, że o ile pierwsza z nich dostrzegała uzasadnienie kary w popełnionym przez sprawcę przestępstwie, o tyle druga usprawiedliwiała jej zastosowanie koniecznością zapobieżenia zachowaniom niezgodnym z prawem. Innymi słowy, zasygnalizowaną powyżej dychotomię, w pewnym uproszczeniu, odzwierciedlał w istocie sui generis „kazus Temidy”, nakazujący rozstrzygnaćc, czy mityczna bogini sprawiedliwości, wyważająca na jednej szali ciężar przestępstwa, na drugiej - dolegliwość zawarta w karze, powinna mieć opaskę na oczach, aby nie widzieć, kogo karze i w jakich okolicznościach zewnętrznych, czy wręcz przeciwnie: powinna mieć oczy szeroko otwarte i patrzeć uważnie w przyszłośćc ${ }^{27}$.

Przechodząc do meritum podjętej problematyki, za reprezentatywną dla pierwszej z zasygnalizowanych powyżej teorii sprawiedliwościowych uznano koncepcję retrybutywna, która będąc przykładem bezwzględnej teorii kary,

${ }^{25}$ E. Krzymuski: Teoryja karna Kanta. Ze stanowiska jego ogólnej nauki o rozumie praktycznym, w: Rozprawy i sprawozdania z posiedzeń Wydziału Historyczno-Filozoficznego Akademii Umiejętności, t. 16, Kraków 1882, s. 287. W prowadzonych w literaturze karnistycznej rozważaniach zwrócono ponadto uwagę na relację zachodząca pomiędzy ideą sprawiedliwości a miłosierdzia. Zob. m.in. F. Ciepły, Sprawiedliwość karania a prawo taski..., s. 35 i 41. Dlatego należałoby zaproponować zgoła odmienną interpretację wzajemnych sprzężeń zachodzących pomiędzy zaakcentowanymi wartościami moralnymi. Stosowne rozwiązanie przedstawionego zagadnienia miałoby zapewnić odżegnanie się od traktowania „bilateralnych relacji” wskazanych wartości w kategoriach konfliktu, co tym samym skutkowałoby zastapieniem omawianej zależności koncepcja hierarchizacji wartości (koordynacji). T. Ślipko, Zarys etyki ogólnej, Kraków 2002, s. 235-237; zob. także P. Rogoziński, Instytucja utaskawienia w prawie polskim, Warszawa 2009, s. 47-57. Odmiennie natomiast na ten temat wypowiedział się B. Janiszewski, Humanitaryzm jako zasada sqdowego wymiaru kary, w: idem (red.), Nauka wobec wspótczesnych zagadnień prawa karnego w Polsce. Ksiega pamiatkowa ofiarowana Profesorowi Aleksandrowi Tobisowi, Poznań 2004, s. 88; A. Grześkowiak, Funkcje kary w świetle projektów zmian kodeksu karnego, w: A. Dębiński, A. Grześkowiak, K. Wiak (red.), op. cit., s. 47-48; autorka jednocześnie zwróciła uwagę, że: „Źródłem sprawiedliwości karnej winna być przyrodzona godność człowieka i szacunek dla każdej ludzkiej istoty”. Zob. też A. Kaufmann, Über Gerechtigkeit, Köln-Berlin-Bonn-München 1993, s. 39.

${ }^{26}$ Wśród przedstawicieli pierwszej z wyróżnionych teorii należy wymienić zwłaszcza: Platona, Arystotelesa, św. Tomasza z Akwinu, jak również H. Grocjusza, S. Puffendorfa, T. Hobbesa, G.W.F. Hegla oraz I. Kanta. Z kolei do reprezentantów drugiej z wymienionych teorii należeli m.in.: J. Bentham i J.S. Mill. Powyższe rozróżnienie uzupełnia wyodrębnienie trzeciej teorii sprawiedliwościowej - prawnopozytywistycznej, która za sprawiedliwe traktowała wyłącznie to, co zostało uzgodnione przez obywateli w ramach zawartej umowy, a następnie zapisane w prawie pozytywnym stanowionym. Za takim ujęciem sprawiedliwości opowiedzieli się m.in.: J. Austin, H. Kelsen i H. Hart. Zob. Z. Kieliszek, Państwo sprawiedliwe wedtug Immanuela Kanta, w: B. Kruszewska, P. Polaczuk, L. Świto (red.), op. cit., s. 44; M.A. Krapiec Człowiek i prawo naturalne, Lublin 1993, s. 48 i n.; U. Steinvorth, Sprawiedliwość, w: E. Martens, H. Schnädelbach (red.), Filozofia. Podstawowe pytania, tłum. K. Krzemieniowa, Warszawa 1995, s. 340-341.

${ }^{27}$ A. Zoll, Wina i kara, „Nauka” 2004, nr 1, s. 39. 
akcentowała równie bezwyjątkową konieczność urzeczywistnienia równowagi pomiędzy winą sprawcy i wymierzoną wobec niego karą ${ }^{28}$. Warto przy tym nadmienić, że przywracanie wspomnianej równowagi zostało przez poszczególnych przedstawicieli retrybutywizmu zinterpretowane w odmienny sposób. Dla Immanuela Kanta posiadało ono wyraźnie moralny charakter, dla Georga W.F. Hegla - logiczno-dialektyczny, dla Friedricha Stahla - religijny, dla Johanna Herbarta - estetyczny, a z kolei dla Karla Bindinga - prawny. Wspólnym natomiast punktem odniesienia zasygnalizowanych uzasadnień retrybutywizmu okazywało się wyraźne zaakceptowanie założenia wskazującego, że naruszony fundament porządku prawnego powinien zostać odbudowany, nawet wówczas, gdy w końcowym rezultacie nie zostałby osiagnięty żaden pozytywny efekt, oceniany z perspektywy jednostkowej bądź społecznej.

Bliższą charakterystykę głównych tez retrybutywizmu należałoby niewątpliwie poprzedzić próbą wyjaśnienia niniejszego terminu. W doktrynalnych rozważaniach zwrócono uwagę, że łacińskie słowo retribuere tłumaczono najczęściej jako: „zapłatę, spłatę, zwrot należności, rekompensatę” czy wreszcie „wyrównanie/nagrodę, związaną z czyimś zachowaniem”. Z etymologicznego punktu widzenia wynikało zatem, że objaśniany termin posiadał prywatnoprawne konotacje i - w konsekwencji - początkowo jego sens wiązano z cywilnoprawnym długiem lub zobowiązaniem podatkowym ${ }^{29}$. Dopiero $\mathrm{w}$ późniejszym okresie retrybucję zaczęto odnosić do odpłaty - dobrem za dobro lub złem za zło, wzbudzając w ten sposób już pewne asocjacje natury penalnej. Podstawowa zaś reguła, dyktująca retrybutywny wymiar kary, była surowa zasada ius talionis, zgodnie z która, orzeczona kara powinna swoja dolegliwością odpowiadać wymiarowi zła, jakiego dopuścił się sprawca przestępstwa. Zaakcentowane $\mathrm{w}$ ten sposób, stricte odwetowe „przetaryfikowanie” wspomnianego „zła” na rodzaj oraz rozmiar sankcji spowodowało, że przeciwnicy twardych zasad retrybucji określali ją nierzadko mianem idei, zawierającej w sobie: „wylewanie tępej złości”, „wynik animalnych instynktów ludzkiej natury”, ,pierwiastek fideistyczny”, „mściwe odczuwanie”, „,zakorzeniony przedcywilizacyjny i niewyznawany dziś już instynkt”, „atawizm”, „prymitywizm i barbarzyństwo". Natomiast reprezentantów idei kary odwetowej, jak egzemplifikowano w doktrynie, nazywano najczęściej ludźmi „mściwymi”, „zacofanymi”, w najlepszym układzie „zalęknionymi”’”.

${ }^{28} \mathrm{Nie}$ bez racji podniesiono przy tym $\mathrm{w}$ piśmiennictwie, iż locus classicus teorii sprawiedliwości, a co za tym idzie - jednej z dwóch zasadniczych koncepcji sprawiedliwej kary, stanowi zawarte w V księdze Arystotelesowskiej Etyki Nikomachejskiej wyróżnienie sprawiedliwości retrybutywnej oraz dystrybutywnej. Zob. także W. Sadurski, Teoria sprawiedliwości, Warszawa 1988, s. 46; W. Zalewski, O pojmowaniu sprawiedliwości $w$ prawie karnym, „Gdańskie Studia Prawnicze” 14, 2005, s. 1104. Zob. także A. Kaufmann, op. cit., s. 42-43; I. Hayduk-Hawrylak, Sprawiedliwej kary conditio sine qua non, w: J. Skorupka (red.), Rzetelny proces karny. Ksiega Jubileuszowa Profesor Zofii Świdy, Warszawa 2009, s. 110-111 i lit. tam podana.

${ }^{29} \mathrm{~F}$. Ciepły, O dowartościowanie retrybutywnej racjonalizacji kary, w: A. Dębiński et al. (red.), Hominum causa omne ius constitutum est. Ksiega jubileuszowa ku czci Profesor Alicji Grześkowiak, Lublin 2006, s. 232.

${ }^{30}$ F. Ciepły, O dowartościowanie..., s. 232-234. 
Dla wyodrębnienia dalszych, a przy tym podbudowanych stosowna argumentacją teoretyczna, założeń idei retrybutywnej szczególnie doniosły pozostaje dorobek naukowy Kanta ${ }^{31}$. Analiza wybranych pozycji filozoficznych wspomnianego autora pozwoliła bowiem na sformułowanie trzech, wzajemnie powiązanych ze sobą tez, odnoszących się do retrybutywnego sensu karania. Stosownego zaakcentowania wymagały następujące założenia: 1) kara znajduje usprawiedliwienie tylko wówczas, gdy jest zasłużona, 2) kara uzyskuje przymiot zasłużonej jedynie wtedy, gdy ukarany wyrządził zło z wolnej woli, 3) surowość zasłużonej kary jest równa ciężarowi przestępstwa ${ }^{32}$. Ideologia karna Kanta akcentowała więc, że podstawową oraz zasadniczą reguła, kształtująca rodzaj oraz wysokość wymierzanej kary, stanowi wspomniane ius talionis. Jednocześnie należy zaznaczyć, że istotną oraz nieprzemijająca wartością teorii filozofa było również wyeksponowanie w niej winy, jako granicy karania $^{33}$. Powyższe założenia uzupełniało zresztą słynne Kantowskie przekonanie o potrzebie ukarania ostatniego żyjącego na wyspie przestępcy w imię bezwzględnie pojmowanej sprawiedliwości. W myśl łacińskiej maksymy, Fiat iustitia, pereat mundus ${ }^{34}$, Kant stwierdzał bowiem, że: „Gdyby nawet społeczność obywatelska miała się rozwiązać, bo tak postanowili jej członkowie [...], to odsiadujacy więzienie morderca musi zostać stracony, zanim to nastapi, tak aby każdy odczuć mógł wagę jego zbrodniczych czynów i by zmyta została krew, która splamiłaby cały lud, gdyby odstapiono od wykonania kary. W przeciwnym razie lud byłby współwinny tej publicznej obrazy sprawiedliwości”35.

W tym miejscu należy także podkreślić, że - wyróżniony w Kantowskim modelu retrybutywizmu - odwet posiadał charakter formalny. W ten bowiem sposób starano się zaznaczyć, że postulowany ideał karnej wzajemności okazywał się niekiedy bardzo trudny do zrealizowania w praktyce, skoro nie zawsze było możliwe „odtworzenie” lustrzanego odbicia materialnoprawnych znamion przestępstwa w następstwie wymierzanej kary ${ }^{36}$. O konieczności zachowania odstępstwa od bezwzględnego przestrzegania zasady głoszącej, iż przestępcę należy potraktować w taki sam sposób, w jaki on postapił, łamiąc obowiązujace regulacje prawne, przekonywał także inny reprezentant retrybutywnej teorii kary - Hegel. Interpretacja dzieł wymienionego filozofa utwierdzała również w przeświadczeniu, że bezwzględne egzekwowanie reguły „to samo

31 A. Kaufmann, op. cit., s. 42; M. Piechowiak, W poszukiwaniu ontologicznych podstaw prawa. Arthura Kaufmanna teoria sprawiedliwości, Warszawa-Poznań 1992, s. 48-49; Ch. Perelman, op. cit., s. 208 i n.

${ }^{32}$ M. Królikowski, Sprawiedliwość karania w społeczeństwach liberalnych. Zasada proporcjonalności, Warszawa 2005, s. 81.

33 A. Marek, Prawo karne, Warszawa 2003, s. 238. Autor jednocześnie zwrócił uwagę, że walor czysto teoretyczny posiadała abstrakcyjna koncepcja Hegla, traktująca karę dialektycznie jako negację przestępstwa, przywracającą ideę prawa.

${ }^{34}$ K. Kuźmicz, Teoria karna Immanuela Kanta w pogladach Edmunda Krzymuskiego, ,Miscellanea Historico-Iuridicia” 4, 2006, s. 81.

${ }^{35}$ I. Kant, Metafizyka moralności, tłum. E. Nowak, Warszawa 2005, s. 181.

36 M. Chmieliński, Prewencja czy retrybucja? Artykut 53 kodeksu karnego w świetle koncepcji penologicznej Immanuela Kanta, w: J. Miklaszewska, P. Spryszak (red.), Kant wobec problemów wspótczesnego świata, Kraków 2006, s. 146. 
za to samo" (Gleiches mit Gleichem) nie zawsze było realnie osiagalne. Nie bez cienia ironii egzemplifikował on, że kara, postrzegana jako tradycyjny odwet, może - w określonych przypadkach - razić wręcz swoją absurdalnością. Ujmujac nieco lapidarnie, wspomniany filozof stwierdził, że trudno byłoby odnaleźć jakiekolwiek uzasadnienie stosowania retrybutywnej formuły „oko za oko”, „ząb za ząb”, zwłaszcza w sytuacji, gdyby przestępca okazał się osoba bezzębną bądź ślepa ${ }^{37}$.

Odnosząc się z kolei do utylitarnych postulatów karania sprawców przestępstw, należałoby w pierwszej kolejności zwrócić uwagę, że w ujęciu tym zaproponowano trzy główne strategie oddziaływania: prewencję specjalna, reedukację oraz prewencję ogólna. W odróżnieniu od retrybutywizmu wspomniany utylitaryzm powierzył sankcji kryminalnej zasadniczą rolę w osiagnięciu korzystnych rezultatów, osiaganych w ramach procesu karania ${ }^{38}$. Spodziewane efekty wiązano przy tym z zapobieganiem przestępczości, nie tylko w wymiarze jednostkowym, przez „uzdrawiajacy” wpływ na psychikę sprawcy, lecz także w aspekcie ogólnospołecznym, w drodze negatywno- bądź pozytywnoprewncyjnego oddziaływania. Wyróżnione powyżej trzy zasadnicze cele prewencyjne nie uzyskały przy tym jednogłośnej akceptacji w doktrynie. Kontestatorzy utylitarnych teorii kary podnosili konsekwentnie, że wymienione założenia wzbudzają wiele kontrowersji o charakterze merytorycznym. W odniesieniu do celu szczególnoprewencyjnego zwracano uwagę, że jego zaaprobowanie byłoby równoznaczne w skutkach z oderwaniem surowości kary od stopnia winy. W wysuwanej argumentacji podnoszono bowiem, że znajdujace się w centralnym punkcie prewencji indywidualnej dążenie do zapobieżenia kolejnemu przestępstwu przez ukaranego sprawcę nie jest jednoznacznie: „[...] sprzężone ze stopniem zawinienia przy popełnieniu danego przestępstwa"39. Ponadto, od krytycznych uwag - których pojawienie się wynikało przede wszystkim ze sceptycznej oceny samej możliwości rehabilitacji sprawcy - nie były również wolne indywidualnoprewencyjnie zabarwione propozycje utylitarystów, domagających się zastapienia karania określonym procesem terapeutycznym.

Zgłaszane zastrzeżenia nie ominęły również wspomnianych celów o charakterze ogólnoprewencyjnym. Odwołując się do głównych założeń prewencji ogólnej negatywnejej, podniesiono, że jej naczelne przesłanie, prokla-

37 J.G. Murphy, Trzy pomytki dotyczqce retrybutywizmu, w: J. Hołówka (red.), Filozofia moralności: wina, kara, wybaczenie, Warszawa 2000, s. 243-244.

38 E. Klimowicz, Utylitaryzm, w: Stownik pojęć filozoficznych, red. W. Krajewski, Warszawa 1996, s. 205-206.

39 W. Sadurski, op. cit., s. 258 i n.

${ }^{40} \mathrm{Na}$ temat negatywnej prewencji ogólnej oraz czołowego jej przedstawiciela P.J.A. Feuerbacha zob. w szczególności: D. Janicka, Nauka o winie i karze $w$ dziejach klasycznej szkoły prawa karnego $w$ Niemczech $w$ I połowie XIX w., Toruń 1998, s. 211; K. Buchała, A. Zoll, W stupięćdziesięciolecie śmierci Paula Johanna Anzelma von Feuerbacha, „Państwo i Prawo” 1983, z. 12, s. 29; W. Wolter, Zarys systemu prawa karnego, t. 2, Kraków 1934, s. 14; J. Bohnert, Paul Johann Anselm Feuerbach und der Bestimmtheitsgrundsatz im Strafrecht, Heidelberg 1982, s. 12; W. Hassemer, Einführung in die Grundlagen des Strafrechts, München 1990, s. 309; zob. również P.J.A. Feuerbach, Revision der Grundsätze und Grundbegriffe des positiven peinlichen Rechts, Teil I, Erfurt 1799, s. 40 i n. 
mujące ideę odstraszania innych osób niż sprawca przestępstwa, podważa przede wszystkim związek pomiędzy winą a surowością kary. Lekceważąc zatem wszelkie granice aksjologiczne, idea prewencji negatywnej nie pozwalała na udzielenie odpowiedzi na pytanie - kogo i jak surowo należy karać. Zdaniem Herberta L.H. Harta, słabością omawianej strategii było przede wszystkim odwrócenie się od traktowania sprawcy jako podmiotu moralnego, co wynikało z przyjęcia apriorycznego założenia, że powinien on cierpieć w imię tego, aby „[...] inni poczuli się zmuszeni do większego posłuszeństwa względem prawa" ${ }^{41}$. Stąd też wyrażano przekonanie, że: „Cel odstraszania jest więc osiagnięty, gdy ukarzemy »kozła ofiarnego", który w oczach opinii publicznej jest winny popełnienia przestępstwa"42. Próbujac skompromitować omawianą strategię, nieco od innej strony zwracano również uwagę na to, że sprawcy przestępstw działają najczęściej pod wpływem impulsu, bez dokonywania „wstępnej” analizy surowości hipotetycznej sankcji, licząc jednocześnie, że ominie ich kara ${ }^{43}$. Parafrazując słowa Denisa Szabo, można by więc dopowiedzieć, że emanacja strachem, pociagająca za sobą zwiększanie represyjności, nie jest skuteczną metoda powstrzymania potencjalnych sprawców od popełniania przestępstw, skoro podobnie jak niektóre wirusy, przyzwyczajone do stosowanych przeciwko nim określonych środków medycznych, wykazują finalnie odporność na skuteczność ich działania, nawet gdyby nastapiło zintensyfikowanie składu związków chemicznych ${ }^{44}$.

Od wysuwanych kontrargumentów nie była również wolna druga z odmian prewencji generalnej, tzw. prewencja generalna pozytywna, zakładajacca, że naczelnym zadaniem wymierzonej kary powinno być zintegrowanie społeczeństwa wokół poszanowania wartości prawa, a tym samym zapewnienie stabilizacji obowiązującym normom ${ }^{45}$. Podając w wątpliwość sprawiedliwościowe atrybuty sankcji karnej, racjonalizowanej pozytywnoprewencyjnie, w piśmiennictwie stwierdzono, że nie istnieje bowiem żadna pewność, aby kara, uwzględniająca wspominane treści utylitarne, rzeczywiście umocniła moralne skrupuły społeczeństwa ${ }^{46}$. Równie sceptycznie oceniono prezentowany w literaturze wniosek o - rzekomych - zainteresowaniach społeczeństwa pojęciem

\footnotetext{
${ }^{41}$ A. von Hirsch, Uzasadnienie istnienia i wymiaru kary we wspótczesnym retrybutywizmie, „Ius et Lex” 2006, nr 1, s. 55.

${ }^{42}$ W. Sadurski, op. cit., s. 260.

${ }^{43}$ M. Królikowski, T. Krawczyk, Raport o Raporcie... Rzecz o poszukiwaniu kary sprawiedliwej, „Studia Iuridica” 29, 2001, s. 120.

${ }^{44}$ D. Szabo, Kryminologia i polityka kryminalna, tłum. K. Piasecki, Warszawa 1987, s. 197.

${ }_{45}$ Zob. w tym zakresie m.in.: E. Durkheim, Zasady metody socjologicznej, tłum. J. Szacki, Warszawa 1968, s. 37-38; J.Ch. Müller-Tuckfeld, Integrationsprävention. Studien zu einer Theorie der gesellschaftlichen Funktion des Strafrechts, Frankfurt am Main-Berlin-Bern-New YorkParis-Wien 1998, s. 213; J. Bentham, Wprowadzenie do zasad moralności i prawodawstwa, tłum. B. Nawroczyński, Kraków 1958, s. 236; I.B. Nestoruk, Zasada ultima ratio na przyktadzie niemieckiego prawa karnego, w: T. Dukiet-Nagórska (red.), Zagadnienia wspótczesnej polityki kryminalnej, Katowice 2006, s. 28; C. Beccaria, O przestepstwach i karach, tłum. E.S. Rappaport, Warszawa 1959, s. 139.

${ }^{46}$ A. von Hirsch, op. cit., s. 56.
} 
winy czy kary proporcjonalnej ${ }^{47}$. W krytycznych uwagach podnoszono także, iż komentowana koncepcja prewencyjna, traktująca karę jako bodziec do przestrzegania prawa, nie respektuje również moralnego statusu sprawcy, skoro z założeń samej teorii nie wynika, że: „[...] potępienie moralne przez karę ma rzeczywiście podstawy moralne" ${ }^{48}$. Ogólnoprewencyjnie zorientowany wymiar kary wzbudzał przy tym zastrzeżenia nie tylko o charakterze stricte teoretycznym, lecz także praktycznym. Na podkreślenie zasługują w tym miejscu słowa Helmuta Marquardta, iż żadne badania empiryczne nie są w stanie wykazać, czy określona wysokość kary posiada zamierzony skutek odstraszający. Podobnie, jak zaznaczył autor, nie można również stwierdzić, że określony wymiar kary, bardziej niż inny, przyczynia się do stabilizacji normy ${ }^{49}$.

\section{UWAGI KOŃCOWE}

Przeprowadzone rozważania nie stwarzają zatem podstaw do mówienia o zwrocie kopernikańskim, oscylującym pomiędzy wyborem klasycznej koncepcji odpłaty a tendencja, aprobującą szczególno- bądź ogólnoprewencyjne założenia prawa karnego $0^{50}$. Naczelne przesłania dwóch zasadniczych teorii kary kryminalnej oraz kierowane pod ich adresem zastrzeżenia utrudniają niewątpliwie określenie ad hoc komponentów, w jakie powinien zostać wyposażony „ideał kary”, uosabiany przez „karę sprawiedliwa”. Stąd też może pojawić się pytanie, czy dążenie do objaśnienia, czym jest kara sprawiedliwa, powinno opierać się na wymienionych koncepcjach, czy też bardziej postulowane byłoby poszukiwanie nowych koncepcji, które mogłyby uzyskać akceptację ze strony współczesnej, sprawiedliwościowej myśli penalnej ${ }^{51}$.

${ }^{47}$ B. Schönemann, A. von Hirsch, N. Jareborg, Positive Generalprävention, Heidelberg 1988, s. $125-139$.

${ }^{48}$ A. von Hirsch, op. cit., s. 58.

${ }^{49} \mathrm{H}$. Marquardt, O teoretycznym i praktycznym znaczeniu celów kary $w$ zachodnioniemieckim prawie karnym, w: T. Kaczmarek (red.), Teoretyczne problemy odpowiedzialności karnej $w$ polskim oraz niemieckim prawie karnym. Materiaty Polsko-Niemieckiego Sympozjum Prawa Karnego, Karpacz maj 1990, Wrocław 1990, s. 124.

${ }^{50}$ Ibidem, s. 130.

${ }^{51}$ Równie kontrowersyjne opinie wzbudza wyróżniana w doktrynie prawa karnego sprawiedliwość naprawcza. Zwolennicy wymienionej idei realizacji karania sprawców podkreślali, że wymieniona koncepcja, zestawiana zwłaszcza z ideą retrybutywizmu, zdecydowanie lepiej koreluje z aktualnymi potrzebami społeczeństwa. Według założeń sprawiedliwości naprawczej reakcja na przestępstwo nie powinna stanowić odwetu, ale uosabiać dążenie sprawcy do pojednania się z pokrzywdzonym oraz do rzeczywistego wyrównania szkody, której w wyniku popełnionego przestępstwa doświadczyły wszystkie dotknięte nim osoby. Chodzi tu zatem nie tylko o podmioty „bezpośrednio" zaangażowane w czyn przestępny - ofiarę oraz sprawcę, ale również o osoby „wtórnie” w nim uczestniczące, czyli o społeczność lokalną. Przy takim założeniu kompensacja szkody, jakiej doznał pokrzywdzony, stanowi jeden z elementów sprawiedliwości naprawczej, która swoim zasięgiem zmierza także do celu w postaci odbudowania zachwianego ładu i porządku społecznego, a ściślej mówiąc, relacji przebiegających na płaszczyźnie: ofiara-sprawca-społeczność. W. Zalewski, Wspótczesna polityka kryminalna zagrożeniem dla praw człowieka?, „Gdańskie Studia Prawnicze” 13, 2005, s. 426-427; idem, Sprawiedliwość naprawcza. Poczatek ewolucji prawa karnego?, Gdańsk 2006. 
Z perspektywy zaś fundamentalnych, a przy tym głęboko zakorzenionych w tradycji standardów karania wydaje się, że klasycznie ujmowane względy sprawiedliwościowe (powiązane na gruncie rodzimego ujmowania kary „sprawiedliwej” z oceną stopnia winy sprawcy oraz stopnia społecznej szkodliwości czynu) nie powinny marginalizować także względów indywidualnoprewencyjnych oraz szeregu okoliczności związanych z czynem oraz osobą sprawcy ${ }^{52}$. Forsowany w ten sposób postulat kompleksowego rozpoznania czynu oraz osoby sprawcy, niewyłączajacy in concreto preponderancji jednego ze wskazanych celów karania, mógłby - przynajmniej w pewnym stopniu - stwarzać gwarancje uzyskania sprawiedliwego rozstrzygnięcia.

\author{
dr Agnieszka Kania \\ Uniwersytet Zielonogórski \\ a.kania@wpa.uz.zgora.pl
}

Zasadniczym przesłaniem sprawiedliwości naprawczej okazuje się jednak wyeksponowanie roli ofiary. Przesunięcie obiektywu i zmiana ogniskowej na osobę pokrzywdzonego miała służyć zapewnieniu ofierze aktywnego uczestnictwa w jej własnej sprawie. Założenie to jednak krytycznie oceniał H.J. Hirsch, stwierdzając, że: „Mówi się o postawieniu na pierwszym planie ochrony ofiar, a tak naprawdę chodzi tylko o dalszy demontaż prawnokarnej reakcji przeciw sprawcy” (idem, Wiedergutmachung des Schadens im Rahmen des materiellen Strafrechts, „Zeitschrift für die gesamte Strafrechtswissenschaft" 1990, Heft 3, s. 544). Oznaczało to tym samym, że pozornie silny argument modelu restorative justice budził w istocie wiele kontrowersji. Zdaniem F. Ciepłego zasadniczej krytyki wymagało przede wszystkim utożsamianie przestępstwa z pojęciem „konflikt”, skoro etymologicznie oznacza on relację pomiędzy agresorem i kimś, kto się broni. Postępowanie karne wszczyna się natomiast nie na podstawie relacji interpersonalnych, jak przekonuje autor, ale na podstawie czynu. Ponadto w sceptycznie ocenianej sprawiedliwości naprawczej podniesiono także, że: „[...] człowiek może, ale nie musi chcieć (»musieć chcieć» to antynomia) ani się poprawić, ani pojednać, ani dobrowolnie naprawić wyrządzonej szkody. [...] Ofiara przestępstwa ma przede wszystkim prawo, aby sąd sprawcy wymierzył sprawiedliwą karę. Wynika to z zasady sprawiedliwości. Tę zasadę może złagodzić wyłącznie ideał miłosierdzia i na tym ideale dopiero może być budowana mediacja”, F. Ciepły, Sprawiedliwość naprawcza wobec przestepstwa, w: A. Gretkowski, D. Karbarz (red.), Mediacja $w$ teorii $i$ praktyce, Stalowa Wola 2009, s. 189 i n. Oznaczałoby to tym samym, że dopiero przyjęcie ostatniego z założeń mogłoby zabezpieczyć komentowaną sprawiedliwość naprawczą przed utożsamieniem jej z utopijną idea. Nie wgłębiając się jednak w szczegółowe analizy wspomnianej problematyki, warto w tym miejscu odwołać się także do słów J. Kochanowskiego, którego zdaniem wymieniony rodzaj sprawiedliwości uosabiał w rzeczywistości odmianę współczesnego abolicjonizmu, podważającego sens kary oraz negującego prawo do jej wymierzania (idem, Powrót kary sprawiedliwej, „Ius et Lex” 2006, nr 1, s. 9). Warto w tym miejscu zaznaczyć, że w piśmiennictwie zwrócono uwagę, iż: „Abolicjoniści kwestionują karę, ponieważ ta nie tylko przysparza skazanemu niepotrzebnych cierpień moralnych i fizycznych, ale pozostawia na nim moralne piętno, znamię, stygmat, który utrudnia powrót do normalnego życia. To nie przestępstwo, ale kara jest rodzajem zbrodni. Kara to społeczne monstrum, głupie, bezskuteczne i odrażające postępowanie z przestępcami. Proces karny w tym świetle to zabawa w moralność, degradująca ceremonia”, F. Ciepły, Sprawiedliwość naprawcza..., s. 189 i n. C. Kulesza, Sprawiedliwa kara a konsensualne formy zakończenia postepowania karnego (uwagi na tle orzecznictwa sqdowego), w: W. Cieślak, S. Steinborn (red.), Profesor Marian Cieślak. Osoba. Dzieło. Kontynuacje, Warszawa 2013, s. 923-941.

${ }_{52}$ Zob. F. Ciepły, Sprawiedliwościowa racjonalizacja wymiaru kary kryminalnej wobec wspótczesnych tendencji polityki karnej w Polsce, Lublin 2017, s. 308 i n. Na temat kontrowersji co do traktowania prewencji ogólnej jako wyznacznika czy „współwyznacznika” kary sprawiedliwej zob. A. Kania, Prewencja ogólna jako dyrektywa sqdowego wymiaru kary. Rozważania na tle Kodeksu karnego, Zielona Góra 2016, s. 251 i n. 


\section{ISSUES OF RETRIBUTIVE AND UTILITARIAN JUSTICE OF PUNISHING}

\section{Sum mary}

This article is devoted to selected problems of a retributive and utilitarian idea of just punishment. It draws attention to the traditional controversies related to the philosophical and legal explanations of the aforementioned justice, which are also eloquently reflected in the field of criminal liability. The analyses conducted reinforce the belief that the attempt to define justice (also the justice of punishing) belongs to the most intriguing challenges of the contemporary times. The doubts identified within the retributive and utilitarian idea of punishment do not provide a clear answer to the question of what components should be attached to the 'ideal punishment' identified with a just penalty. Therefore, the question arises whether the pursuit of an explanation - what in fact is a fair punishment - should be based on these concepts, or whether it would be more appropriate to seek new concepts, capable of being accepted by the modern justice-related penal approach. 